\title{
A fókuszcsoportos vizsgálat kimenetelét befolyásoló tényezők
}

\section{Bevezetés}

Az utóbbi években a fókuszcsoportok ${ }^{1}$ Magyarországon is egyre népszerúbbek. Ezek csoportos interjúk, vagy talán még találóbb, ha csoportos beszélgetésként definiáljuk óket. A csoportok fókuszáltak abban az értelemben, hogy valamilyen kollektív tevékenységre irányulnak, vagy legalábbis a résztvevók egy témára koncentrálnak (Barbour és Kitzinger 1999). A fókuszcsoportos beszélgetéseken többnyire 6-12 fó vesz részt. A fókuszcsoportot az úgynevezett moderátor vezeti. A moderátor feladata, hogy biztosítsa, hogy a résztvevók a témára fókuszálnak, és ó teszi fel a fóbb kérdéseket. Gyakori, hogy a résztvevóket bátorítják az egymással való interakcióra, beszélgetésre, és arra, hogy tegyenek fel egymásnak is kérdéseket. A fókuszcsoportnak minimális kritériuma, hogy a résztvevók hallgatóságot jelentsenek egymás számára (Kitzinger 1994). A fókuszcsoportokat általában videokamerával rögzítik.

A tanulmányban bemutatjuk, hogy a fókuszcsoportok konkrét szituációjának milyen jellemzói vannak kihatással arra, hogy mi hangzik el a fókuszcsoportokon. Több példával is illusztráljuk az egyes tényezók múködésének mikéntjét. Példáinkat nagyrészt személyes tapasztalatunkból és kutatói praxisunkból merítjük. Egyes esetekben, ha saját gyakorlatunkból nem találunk elég szemléletes példát, akkor mások kutatási tapasztalataira hagyatkozunk. Ezután amellett érvelünk, hogy a bemutatott befolyásoló tényezóket a fókuszcsoport-eredmények elemzése során is hasznos figyelembe venni. Ennek hangsúlyozását különösen azért véljük fontosnak, mert bár több fókuszcsoportos könyv foglalkozik a csoportok menetét befolyásoló tényezókkel, ${ }^{2}$ ugyanakkor ennek jelentóségét

\footnotetext{
${ }^{1}$ A fókuszcsoportok módszeréról az alábbi munkákat ajánljuk az olvasó figyelmébe: Carey 1994; Kitzinger 1994, 1995; Krueger 1988; Morgan 1993; Morgan és Krueger 1998; Stewart és Shamdasani 1990.

² Lásd például Fern 2001; Stewart és Shamdasani 1990.
} 
elsósorban a csoportok szervezése szempontjából tárgyalják, és többnyire nem írnak arról, hogy ezekre a szituációs tényezókre az elemzés során is ki kellene térni. Újabban egyes írások ugyan elkezdtek kiállni amellett, hogy fontos a kontextuális tényezók bevonása az elemzésbe (Kitzinger 1994, Kid és Parshall 2000), de ezekben nagyrészt csak a befolyásoló faktorok egy szúkebb alcsoportjára: a csoportszituációból következó dinamikai folyamatokra koncentrálnak.

\section{A befolyásoló tényezők}

A fókuszcsoportok eredményét befolyásoló tényezók közé tartoznak az interakciós tényezók, a személyes jellemzók, a környezet, az idótényezók, a tartalom és a megfigyelés ténye.

\section{INTERAKCIÓS TÉNYEZÓKK}

Mivel a fókuszcsoport csoportos tevékenység, ezért a beszélgetések menetét különbözó szociálpszichológiai, pszichológiai mechanizmusok befolyásolják, amelyek akkor jelentkeznek, ha több ember egymással interakcióba lép. Az egyik ilyen jelenség a konformitás: amikor az egyének annak hatására, hogy más egyének ítéleteivel, attitúdjeivel szembesülnek, megváltoztatják nyílt viselkedésüket és/vagy belsó meggyózódésüket oly módon, hogy az hasonlítson a többiekére. A konformitásnak két fajtáját különböztethetjük meg: a nyilvános konformitást (engedelmeskedést) és a magánkonformitást (megtérést). Nyilvános konformitás esetén az egyén nem azt közli a csoport tagjaival, ami a belsó meggyớzódése, hanem azt a nézetet, ami a többiek álláspontja. Magánkonformitás esetén viszont maga a belsó vélemény is módosult, így nincs diszkrepancia a belsó attitúd és a közölt információ között (Hewstone et al. 1995).

A konform viselkedést két fó okra szokták visszavezetni: az információs és a normatív befolyásra. Ezek a konformitás egyes fajtáival is összefüggenek. Információs befolyás esetén a vélemények információértéke van ránk hatással: megbízunk a megismert új információban, és ennek hatására módosul belsó meggyớzódésünk. A normatív befolyás arra a jelenségre utal, hogy szeretnénk,ha a csoport tagjai kedvelnének minket, és ennek érdekében alkalmazkodunk nyíltan hangoztatott véleményünkkel a többiekéhez (Hewstone et al. 1995).

Jelen írás szerzóje személyesen is megtapasztalhatta a nyilvános konformitásra irányuló belsó nyomást, a csoportszituációból eredó befolyásoló hatást. Még szociológus diákként részt vettem egy divatlapról szóló fókuszcsoporton, amit egy közvéleménykutató cégnél tartottak - szociológus hallgatók számára 
demonstrálandó a módszert. A résztvevók közül egy lányt ismertem, a többiek más egyetemról jöttek, mint én. Bár a csoport célja a módszer bemutatása volt, de teljesen úgy zajlott, mint egy „valódi” csoport, és elképzelhetó volt az is, hogy esetleg a cég valamilyen szinten felhasználja a csoportból származó eredményeket. Elsó feladatként le kellett írnunk, mi jut eszünkbe a divat szóról, és hogyan definiálnánk a divat kifejezést. Ezután egyenként fel kellett olvasni, amit leírtunk. Ahogy a többieket hallgattam, úgy éreztem, hogy ók sokkal ötletesebbeket írtak, ráadásul szociológiai megközelítést is alkalmaztak. Mikor rám került a sor, mivel nem szerettem volna, hogy azt gondolják, én nem tudom hasonlóan találó szavakkal jellemezni a divatot, vagy, hogy úgy véljék, szociológusi múveltségem a divatszociológia terén lemarad az övéktól, 1́gy „hozzáköltöttem” egyet s mást a korábban általam leírtakhoz, felhasználva azt is, amit ók korábban elóttem elmondtak. A fókuszcsoportos cég alkalmazottai a csoport során kellóen meggyózódhettek a szociológus hallgatókkal tartott csoportok nehézségeiról. Az az érdekes helyzet alakult ki ugyanis, hogy a résztvevók többsége azt állította, hogy ók nem követik a divatot, a divatot követóket elítélték, és amikor egy divatlap megtervezése volt a feladat, végül is a csoport egy antidivatlap-tervvel állt eló. Amikor a csoportot szembesítették a tesztelendó divatlappal, a többség nem volt hajlandó figyelmesen megnézni a lapot. Bár bizonyos szempontból magam is rokonszenveztem az antidivat-elképzelésekkel, úgy véltem a csoportunk tagjai túlzásba esnek a divatellenességgel. A tesztelendó divatlapról pedig úgy gondoltam, hogy kifejezetten színvonalasabb, mint az addig Magyarországon kapható hasonló lapok. Ezeknek az eltéró nézeteimnek a csoport során ugyan hangot adtam, de csak korlátozott mértékben. A csoport után együtt buszoztam hazafelé azzal a lánnyal, akit ismertem, és kiderült, az ó véleménye sok szempontból egyezett az enyémmel, csak a csoporton a többiek elítélésétól tartva ó sem igazán mert hangot adni ennek.

A konformitási hajlandóságot befolyásolhatja a csoportban tapasztalható külsố nyomásgyakorlás is. Elófordulhat, hogy a többségtól eltéró véleményt kifejtó egyént a többiek „megtámadják”. Nézzünk erre egy példát egy magyarországi nyugdíjas fókuszcsoportból, ahol a résztvevók bizonytalanságérzete volt a téma. ${ }^{3}$ Károly ${ }^{4}$ vehemensen képviselte azt az álláspontot, hogy a lehetóségek, álláslehetóségek mindenki számára adottak a mostani rendszerben. A csoport többi tagját ez a hozzáállás negatívan érintette, mert egyrészt ók anyagi bizonytalanságra panaszkodtak, másrészt többen közülük bizonytalannak érezték gyerekeik lehetóségeit, és volt olyan is, akinek munkanélküli volt a gyereke vagy a házastársa:

\footnotetext{
${ }^{3}$ A bizonytalanságérzetre vonatkozó fókuszcsoportos vizsgálatról bóvebben lásd: Vicsek 2004.

${ }^{4}$ A neveket megváltoztattuk az anonimitás megórzése érdekében.
} 
Károly: - Egy biztos, hogy most megvannak a lehetóségek. Sült galamb senkinek nem repül a szájába, de akinek megvan a lehetósége, képességei birtokába, tehát, na most, az egyre magasabbra tud emelkedni, több jövedelemre tud szert tenni. Most nyilvánvaló, van aki föl fog érni a csillagos égig, van, aki meg le fog maradni. Versenyhelyzet van. Csak azért mondom, mert én is találkoztam olyan 27 éves gyerekkel vagy vállalkozóval, hogy hogy hívják, évi 50 milliót keresett. Olyan is van, aztán egy fiatal volt...

Péter: - No, de egy pillanatra, az én lányom 43 éves, van neki kereskedelmi szakközépiskolája, és nem tud elhelyezkedni. Mert már 40 éven felül van.

Anett: - Ez így van.

Károly: - Én a rendszerváltás után 55 éves koromban cseréltem munkahelyet.

Anett: - Szerencséd volt, mert...

Mária: - De oda is csak egy ember kellett. [Folyton egymás szavába vágnak, egyszerre beszélnek.]

Péter: - Nem szabad így nézni, Károly [a kezével szemellenzót mutat], ne csak magadról beszélj!

Mária: - Mert ha három osztályt összevonnak, és bejött ez a számítógép, meg bejött, hogy a titkárnó csinál mindent, ahol volt három osztály, és a három osztályon dolgoztak teszem föl tizenöten, és most van egy osztály, és csak dolgoznak öten, akkor most a többi hova menjen el ugyanavval a képesítéssel?

Ildikó: - Aki vállalkozásba kezdett, az mind megbukott...

Mária: - Azért volt jobb a Kádár-rendszerben, mert nem voltak munkanélküliek. Alacsonyak voltak a bérek, de mindenkinek volt munkahelye, és mindenkinek volt fizetése.

Károly: - A vállalkozás nem csak kereskedelemból áll, van termelés is, meg ipari termelés is... A lehetóség adott.

Péter: - Jó, de egyik sem ért veled egyet, Károly, nem.

Károly: - Nem, hát ez nem is kötelezó. De a lehetóségek adottak.

Moderátor: - Ó, mindenféle különbözó vélemények vannak.

Anett: - De evvel [Károly állításával] most én sem értek egyet, mert mondjuk eléggé, egy kicsit olyan kívülállónak érzem magam, már olyan értelemben ... [érthetetlen] /hogy nekem magas a nyugdíjam/. De egyetértek azokkal, akiknek kevés, mert én is tudom, én is vásárolok, meg tudom az értéket, hogy mi az, mert mindenki ebból él, és nagyon sajnálom, hogy a...

Mária: - Nagyon nehéz.

Anett: - De az, hogy neked sikerült 55 évesen váltani, az egy óriási szerencse. De nyugodtan mondjuk azt...

Károly: - Vagy tudás kérdése.

Anett: - Nemcsak a tudás kérdése, mert én ismerek olyan diplomás embert, akit 50 fölött egyszerúen kitették, és nem kellett sehová sem. Hát itt volt a legjobb barátunk, 59, 51 éves korában megszúnt a... Milyen gyár volt a gazda lakótelepen?

Péter: - FESZI, a FESZI, az ötvözetgyár, az ötvözetgyár. 
Anett: - Mindegy. Ötvözetgyár, igen. Pénzügyi osztályvezetó volt. Tanult ember, fóiskolát végzett, 51 évesen megszúnt a munkaviszonya neki, sehová nem vették föl. Pedig, pedig, és mi lett a vége? Hogy 59 évesen sajnos elment tólünk, mert nem bírta, nem bírta. És tanult ember volt. Tehát nemcsak a tudás számít, nemcsak a tudás számít. Pedig ó is akart vállalkozni, ó is akart ide-oda...

Mária: - Szerencse is kell hozzá.

Anett: - És nem tudott elkezdeni semmit.

(2001, Salgótarján, nyugdíjasok fókuszcsoportja)

Látható, hogy Károly véleményével a többiek nem értenek egyet, és erre fel is hívják a figyelmét, illetve Péter kifejezetten negatívan értékeli Károly megnyilvánulását. Moderátorként a helyszínen éreztük azt is, amit a gépelt anyag nem ad vissza, hogy az addig oldott légkör feszültté vált, és a csoporttagok indulatosan reagáltak Károly kijelentéseire.

A légkör érzelmi intenzitása is befolyásolhatja az elhangzottakat. Az elóbbi nyugdíjas fókuszcsoportban a saját nehéz helyzetüket ecsetelvén több nyugdíjas is közel állt a síráshoz, egyikük el is sírta magát:

Lajos: [rendkívül érthetetlenül, hadarva beszél] - Elnézést kérek, de nekem volt 3 agytrombózisom, meg 2 infarktusom, úgyhogy el szoktam érzékenyülni, meg a nyugdijakkal kapcsolatban magamnak is megvolna a bajom, mert 9 ezer Ft-tal mentem nyugdíjba, most van 43 ezer Ft-om, és van a feleségemnek 27 ezer, a kislányom 25 éves, munka nélkül van otthon. [sírva fakad]

Mária: - Csak ne tessék sírni. Igen, elérzékenyül az ember.

(2001, Salgótarján, nyugdijasok fókuszcsoportja)

Egy ilyen érzelmileg erós intenzitású légkörben nehezebben lehet a többséggel ellentétes nézeteket felvállalni.

A vélemények szabad felvállalására kihatással lehet az is, hogy hányan képviselik a kisebbségi álláspontot. Ha többen vannak azonos állásponton, akkor egyes csoportok során elófordulhat, hogy koalíciók jönnek létre, és ezek összecsapnak egy-egy kérdés megvitatásakor. Módosító tényezó lehet az is, hogy mekkora az eltérés a kisebbségi és a többségi vélemény között, és mennyire homogén a többségi nézet. Egy, a prostituáltak megítélésével foglalkozó budapesti fókuszcsoportos kutatás során a résztvevóktól a toborzás során lekérdeztünk egy szúrókérdóívet. Erre adott válaszaik azt mutatták, hogy a résztvevóknek meglehetósen vegyesek a nézeteik a prostitúcióval és a prostituáltakkal kapcsolatban. ${ }^{5}$ Egyik csoporttag válasza sem volt liberális vagy pozitív minden tekintet-

\footnotetext{
${ }^{5}$ A prostituáltak megítélésére vonatkozó kutatásról bóvebben lásd Vicsek 2003.
} 
ben a prostituáltakkal kapcsolatban. Ugyanakkor csak egy résztvevó akadt, Eszter, aki kizárólagosan konzervatív és negatív véleményeket fogalmazott meg. Az, hogy mindegyik résztvevónek - Eszter kivételével - viszonylag vegyes volt a véleménye, ami pozitív és negatív attitúdbeli elemeket is tartalmazott a prostituáltakkal szemben, valószínúleg elósegítette a szabadabb véleménykifejtést a csoportban. A csoportban sokszor egyetértettek egymással a résztvevók, de sokszor fogalmaztak meg egyet nem értést is. Feltehetóleg Eszter is könnyebben tudta egy ilyen helyzetben képviselni saját álláspontját. Néhány esetben azért meg lehetett figyelni, hogy enyhén módosította az eredeti szúrókérdóívben kifejtett véleményét, hogy ne lógjon ki annyira a csoportból.

Több olyan modell is létezik, amely a közös véleményre irányuló nyomást szakaszokban eltéró erósségúnek feltételezi a kiscsoportok életében: különbözó szakaszokra bontva tárgyalja a csoportfolyamatokat. Az egyik legismertebb modell az alábbi öt szakaszt tartalmazza (Werdy és Langmaid 1997): ${ }^{6} 1$. formálás: ez a befogadás szakasza, itt kell megteremteni azokat a feltételeket, hogy a csoporttagok úgy érezzék, befogadták óket a csoportba; 2. rohamozás: ebben a feszültebb szakaszban összecsapnak a résztvevók eltéró céljai, érdekei, a résztvevók próbálják felmérni egymás „erejét”, ekkor szereznek információkat arról, hogy kinek mekkora a szaktudása, ki az, aki domináns személyiségú stb. 3. szabályozâs: a közös jellemzók, vélemények felfedezése és hangsúlyozása, az elfogadás jellemzi ezt a nyugodtabb, békésebb szakaszt, ekkor alakulnak ki a normák; 4. teljesítés: a csoport azt a tevékenységet végzi, amiért létrejött, együttmúkööve egymással, és ebben a légkörben a modell szerint az egyetértésnek és az egyet nem értésnek is tere van; 5. búcsúzás: a csoport befejezése, a tagok a csoport megszüntetése mellett döntenek. A modell szerint az egyes szakaszok egymás után követik egymást, de újra bekövetkezhet visszatérés a rohamozás fázisába, például akkor, ha új téma merül fel. A modell alapján az egyes szakaszokban eltéró jellegú információkat várhatunk: a szabályozás fázisában például nagyobb mértékúek lesznek az egyetértést kifejezó tartalmak, míg a teljesítés fázisában elvileg már a véleménykülönbségek is jobban felszínre jutnak, koalíciók kialakulása is inkább ekkor várható. A csoporton elhangzottakat nagyban befolyásolja, hogy miként sikerülnek és milyen hosszúak az egyes szakaszok: megfelelóen alakul-e a formálás szakasza, senki nem érzi-e elutasítva magát, milyen hosszú a szabályozás szakasza stb. Megjegyzendô ugyanakkor, hogy sok tényezótól is függ, hogy milyen mértékben alakul ki olyan légkör a fókuszcsoportban, hogy a véleménykülönbségek nem tudnak megjelenni.

\footnotetext{
${ }^{6}$ Egy másik folyamati modell például Foulkesé (Fern 2001). Ez több szempontból is hasonlít az itt bemutatott modellre.
} 
Fontos interakciós tényezó a résztvevók motiváltsági szintje: mennyire motiváltak a résztvevók arra, hogy komolyan részt vegyenek a beszélgetésben. Fókuszcsoportok esetén érdekes lehet, hogy maga a téma keltette-e fel a résztvevók érdeklódését, esetleg kíváncsiak arra, milyen egy fókuszcsoport, vagy inkább pusztán a dijazás miatt vesznek részt a csoportban. Gondot jelentenek a „professzionális fókuszcsoport-résztvevók”, akiknek nagy a tapasztalatuk a fókuszcsoportokkal, és a dijazás miatt vesznek részt a csoportokban (Albrecht et al. 1993).

Jelentốs szerepe van annak is, hogy mennyire sikerül bizalomteli, oldott légkört teremteni a csoportban (Albrecht et al. 1993), ahol az egyes résztvevók úgy érezhetik, hogy szabadon elmondhatják az intimebb dolgaikat is, illetve hangot mernek adni olyan véleménynek is, amely esetleg nem felel meg a társadalmi elvárásoknak. Szükséges lehet egyfajta felmelegedési fázis: a fókuszcsoportok elején kevesebb intimebb információt szelektálnak ki általában a résztvevók, mint a késóbbiekben (Fern 2001). Jelentkezhet a „megtörik a jég”-effektus is: amennyiben egy résztvevó beszámol egy intimebb vagy esetleg a társadalomban bizonyos mértékig elítélt tapasztalatáról, elképzelhetó, hogy ezután a többiek is veszik a bátorságot, és mesélnek hasonló élményeikról (Kitzinger 1994, 1995). Pontosan ez történt az egyik, a prostitúció megitélését vizsgáló fókuszcsoportban:

Moderátor: - Mi a véleményetek a kuncsaftokról, hogy ha már így említettétek?

Eszter: - Biztos az is változó. Aki igényesebb, a jó helyre megy. Szerintem közel azonos helyen állnak, mint a prostituáltak. Legalábbis erkölcsileg.

Sándor: - Szerintem erớs a kíváncsiság hatalma. Ez olyan, mint a kábítószer: az ember legalább egyszer kipróbálja, hogy milyen. Ugyanígy kipróbálja a kurvát is. Én elmondok egy történetet, ha név nélkül marad. Én kint jártam Párizsba, és kipróbáltam egyet. Egy szálloda elótt álltak a lányok, és én odamentem és nézegettem óket. És gyönyörú lányok voltak egyébként, ilyen félvér lányok voltak. 26 éves voltam. Gondoltam kipróbálok egyet...

Moderátor: - És a többi férfi próbálta már esetleg?

Flórián: - Szóval ez volt a célja a történetnek.

András: - Nekem ismeróseim vannak Érden, akik szoktak évente kétszer ilyen medencés bulit rendezni, van ott egy uszoda, és ismerik ott a biztonsági óröket, és így be szoktak menni oda. De eleve nem ilyen 10 perces, hanem egész éjszakás. Szoktak ott lenni kurvák.

Moderátor: - És te mennél esetleg?

András: - Valószínú, nem tudom, múltkor úgy volt, hogy megyek, aztán megbetegedtem.

(2001, Budapest, középfokú végzettségúek csoportja) 
Miután Sándor megosztotta a csoporttal, hogy járt már prostituáltnál, ezután a csoport egy másik résztvevóje, András is beszámolt arról, hogy majdnem részt vett egy összejövetelen, ahol lettek volna prostituáltak.

Befolyásolja az elhangzottakat az is, hogy az interakciók során az egyének a rendelkezésükre álló információkból szelektálnak annak alapján is, hogy mit vélnek érdekesnek beszélgetópartnereink számára, mit tartanak olyan témának, amit jó együtt megvitatni. Éppen emiatt egy téma dominanciája egy fókuszcsoportos beszélgetés során nem feltétlenül jelenti annak a fontosságát. Sim (1998) például egy fókuszcsoport során azt tapasztalta, hogy a résztvevók nem beszéltek arról a tényezóról, amit magától értetódónek tartottak, holott éppen az a terület volt a legfontosabb számukra.

\section{SZEMÉLYES JELLEMZÖK ÉS CSOPORTÖSSZETÉTEL}

A csoport résztvevóinek és a moderátornak a személyes jellemzói is olyan tényezók, amelyek kihatással vannak egy csoport menetére (Stewart és Shamdashani 1990; Fern 2001; Farquhar 1999; Chiu és Knight 1999). A személyes jellemzóknél fontos lehet a személyiség, a fizikai tulajdonságok, a kor, a nem, az iskolai végzettség, a vizsgált témára vonatkozó tudásmennyiség, a társas hatalom, a társadalmi státusz, a formális/informális hierarchiában elfoglalt hely, az etnikai hovatartozás és egyéb társadalmi-demográfiai háttértényezók. A személyes jellemzók két szinten is befolyásolhatják az eredményeket: egyrészt befolyásolják az egyént abban, hogy mit mond, másrészt a csoport összetétele kihatással lehet a csoport viselkedésére. Kimutatták például, hogy elófordul: a férfiak másként nyilatkoznak egy csak férfiakból, mint egy vegyesen férfiakból és nókból álló kiscsoportban (Aries 1976).

Több személyiségmodell is létezik, amelyet alkalmazni szoktak a fókuszcsoport-résztvevók személyes tulajdonságaira (Fern 2001; Stewart és Shamdashani 1990). A csoport összeállításánál is figyelembe lehet venni a jelentkezók személyiségét. A beszélgetések menetét nyilván befolyásolni fogja, hogy a résztvevók mennyire gátlásosak, mennyire nyíltak, extrovertáltak, együttérzóek, dominánsak, határozottak, individualisták, konflikuskeresóek stb. Egyes fókuszcsoportos vizsgálatoknál célszerú lehet kiszúrni az inkább problematikus személyiségúeket. Ugyanakkor el lehet képzelni olyan kutatási célokat is, ahol nem célszerú az ilyen szúrés (mert például éppen azt akarjuk tanulmányozni, hogy mennyire dominál valaki másokat). A korábban már említett „bizonytalanságos” kutatásnál nem volt lehetóségem a nehéz személyiségek kiszúrésére. Az említett nyugdíjas fókuszcsoportban volt egy kirívóan domináns nó: rendkívül nagy 
intenzitással panaszkodott a bizonytalanságról, és alig hagyott másokat szóhoz jutni, ha valaki vele nem egyezó véleményt hangoztatott, azt rögtön megkritizálta. Látható ugyanakkor, hogy Károly határozott egyéniség volt, aki a támadások kereszttû́zében is képes kitartani álláspontja mellett. Egy kevésbé határozott ember valószínúleg nem védelmezte volna ilyen kitartóan az álláspontját.

A résztvevók és a moderátor fizikai jellemzói is kihatással vannak az egymás iránti viselkedésre a csoportban. Az olyan fizikai jellemzók, mint a magasság, súly, öltözködés, megjelenés befolyásolják, hogy mások hogyan tekintenek az egyénre és hogyan viselkednek vele (és ez visszahathat az egyén viselkedésére) (Stewart és Shamdashani 1990).

Az egyéneknek az a képessége, hogy mennyire tudnak befolyásolni valakit egy csoport-szituációban, az ún. társas hatalom (Steward és Shamdashani 1990). A társas hatalom alapulhat többek között jutalmazáson, kényszerítésen, legitimitáson és szakértóségen. Stewart és Shamdashani (1990) hangsúlyozza, hogy általában nem maga a hatalommal rendelkezés ténye, hanem a hatalom percepciója a befolyásoló tényezó. Általában az alacsonyabb státuszú résztvevók kisebb társas hatalommal rendelkeznek.

Az interakciókat befolyásolja, hogy mennyire homogének, illetve heterogének a csoportok a személyes jellemzók szempontjából. A homogén összetétel általában kellemesebb légkört, erósebb csoportkohéziót teremt, és könnyebben értik meg egymást a résztvevók: hasonlóbb lehet a szókincsük, tudásuk, képességeik stb. Általában ilyenkor inkább merik vállalni a résztvevók egyéni véleményüket (Sim 1998). Ha azonos státuszúakból áll a csoport, akkor nem hallgatnak el egyes résztvevók státuszkülönbségek miatt (azonban ritkán sikerül státusz szempontjából teljesen azonos szintú csoportot összehozni). Heterogén csoportösszetétel esetén a magasabb társas hatalmúak válaszai nagymértékben befolyásolhatják a többi résztvevơét. Ezt Michell (1999), egy angliai kutatónó, is tapasztalta a diákok közötti informális hierarchiát vizsgáló kutatásában. A hierarchia múködését már ott is nyomon lehetett követni, hogy a hierarchiában alacsonyabban elhelyezkedó diákok alig szólaltak meg a vegyes hierarchiájú diákokat magukban foglaló fókuszcsoportokban, illetve ha megszólaltak, akkor is csak megerósítették, amit a többiek mondtak. Az alacsony státuszú diákok egyáltalán nem beszéltek a fókuszcsoportokban arról, hogy milyen gyötrelmeket élnek át a hierarchia következtében: erról csak egyéni interjúkban adtak számot a kutatóknak. Ha kutatási célunk a természetes társas kommunikáció vizsgálata és annak feltérképezése, hogy miként érintkeznek egymással a különbözó státuszú diákok, akkor az ilyen vegyes csoport célszerú lehet. Ha azonban azt szeretnénk, hogy az alacsonyabb státuszúak is megszólaljanak, akkor alkalmazhatunk egyéni interjúkat, vagy olyan fókuszcsoportokat, amelyek csak alacsonyabb státuszúakból állnak. Az elóbb említett iskolai kutatás esetén egyéni interjúkat 
alkalmaztak, mert úgy vélte a kutató, hogy megalázó lehetett volna a diákok számára, ha az iskolai ranglétra legalján állókból hoz létre egy fókuszcsoportot.

Azok a résztvevók, akit magas iskolai végzettségúnek tekintenek a többiek és nagy szaktudásúnak, szakértói hatalmat gyakorolhatnak a többiek felett. A korábban már említett nyugdíjasokból álló fókuszcsoportban a nyugdíjrendszerrel kapcsolatos félelmek tárgyalásakor az egyik résztvevó hosszasan sorolt tényadatokat a nyugdíjrendszerról. Ettól a többi résztvevó kicsit „megszeppent”: úgy érezték, hogy ók sokkal kevésbé értenek a témához, ezért az ó véleményük kevésbé lehet releváns. A résztvevóket úgy választottuk ki, hogy iskolai végzettség tekintetében azonos szinten helyezkedjenek el, de ezen felül nem vizsgáltuk az egyes területekre vonatkozó tudásukat. Mivel a többiek véleményére is kíváncsiak voltunk: ezért moderátorként felhívtuk a figyelmet arra, hogy nem a nyugdíjrendszerrel kapcsolatos tények a téma, hanem a hozzá fúzódó érzelmek.

A fókuszcsoportok másként zajlanak, ha ismerósökból, és ha ismeretlenekból állnak. Egyrészt ismerósökból álló fókuszcsoport esetén a résztvevók elképzelhetó, hogy kevésbé fejtenek ki valamit, mert „félszavakból is értik egymást”. Másrészt befolyásolhatja azt, amit elmondanak, hogy egyes információkat a résztvevók össze tudnak vetni azzal, amit a fókuszcsoporton kívül tapasztaltak az illetóvel kapcsolatban (Kitzinger 1995). Harmadrészt, míg egy nagyvárosi, ismeretlenekból álló csoportban a csoport után várhatóan a résztvevók nem fognak találkozni egymással soha többet, addig ismerósökból álló csoport esetén a csoporttagok a fókuszcsoport után is várhatóan találkozni fognak, és így a fókuszcsoporton túl is jutalmazhatják, illetve szankcionálhatják egymást a csoporton elhangzottak miatt. Ismerósökból álló csoport esetén a résztvevók már olyan korábbi kapcsolati viszonyokat hoznak a csoportba, amikról a kutató nem rendelkezik információval (hacsak nem végzett terepmunkát is), és amely befolyásolhatja, hogy ki mit mond a csoportban. További különbség a kétfajta csoportösszetétel között, hogy ismerósökkel beszélgetni egyfajta „természetesebb” szituációt jelent. Az ismeretség foka is hatással lehet az elhangzottakra. A Green és Hart (1999) kutatópáros például azt tapasztalta, hogy másként beszéltek gyerekek a baleseti kockázatokról, amikor olyan fókuszcsoportban kérdezték óket erról, ahol barátaik voltak, és másként olyan csoportban, ahol nem a barátaik, pusztán iskolatársaik voltak. A barátokból álló csoportokban gyakran olyan balesetekkel kapcsolatos történeteket meséltek el a gyerekek, amely baráti csoportosulásuk kollektív emlékezetének a része, a csoport többi tagja is már hallotta a történetet. Ezzel szemben az iskolatársakból álló csoportokban valószínúbb volt, hogy olyan esetról mesélnek, amelyet nem hallott még a csoporttárs, és így az elbeszélés módja is más jellegú volt.

Az, hogy mennyi információval rendelkezik az egyén az adott témáról, a szakértới hatáson túl is befolyásolja a válaszokat. Például néhány éve egy fókusz- 
csoporton a számítógépekhez való hozzáállást vizsgáltam. Ebben a csoportban voltak olyanok is, akik értettek a számítógépekhez, és olyanok is, akik nem. A kérdések nem a tudásszintet mérték, hanem az attitúdöket, de egyes résztvevóknek nehéz volt attitû́döt megfogalmazni olyan jelenségekkel kapcsolatban, amiról azt sem tudták elózóleg egyáltalán, hogy létezik (pl. elektronikus aláírás).

A moderátor személyes jellemzói is hatással lehetnek a beszélgetésre (Farquhar 1999; Chiu és Knight 1999; Fern 2001; Stewart és Shamdashani 1990). Ezt jól illusztrálják egy rákszúréssel kapcsolatos fókuszcsoportos vizsgálat tapasztalatai (Chiu és Knight 1999). Egy kutatócsoport leedsi kisebbségi nók körében vizsgálta a rákszúrési tapasztalatokat, az ehhez való hozzáállást. Azt találták, hogy a moderátor és a jelen lévó kutatók etnikai hovatartozása szignifikánsan befolyásolta a résztvevók megnyilvánulásait a faji kérdésekben, melyek óhatatlanul jelentkeztek a téma kapcsán. Voltak, akik csak a fókuszcsoportok után, a hozzájuk hasonló etnikumú kutatónak árulták el véleményüket a rasszizmusról. A fókuszcsoportok során is úgy túnt, hogy végig tudatában voltak a résztvevók a fehér kutatók jelenlétének, s erre reagáltak is. Az egyik résztvevó például az alábbiakat mondta:

- „Hát, sajnálom, hogy te Debbie [a kutató] fehér vagy, de azt kell, hogy mondjam... sok emberünk korán hal meg az ötvenes éveiben, a rasszizmus miatt, mert nagyon keményen kellett dolgozniuk bevándorlókként ebben az országban."

(Chiu és Knight 1999: 107.)

Nemrégiben láttam videofelvételt egy budapesti fókuszcsoportról, amelynek egyik témája a drog volt. A moderátor egy laza stílusú, raszta-hajú, fiatal férfi volt. Valószínúleg más sült volna ki a beszélgetésból, ha egy tekintélyt keltó, idôsebb férfi vezeti a beszélgetést.

Sokat számít, hogy képes-e a moderátor jó légkört, bizalmat ébreszteni, és rá tudja-e venni a szégyenlósebbeket is, hogy megszólaljanak. A különbözó moderátorok eltérhetnek moderátori stílusukban: például abban, hogy milyen mértékú kontrollt alkalmaznak az egyes csoportok során, mennyire bólogatnak, illetve adnak ki hozzászólást támogató hangokat (oh, hmm stb.). A moderátorok egy része professzionális moderátor, míg a fókuszcsoportok másik részét maguk a kutatók szokták moderálni. A professzionális moderátorok profibbak lehetnek a csoportdinamika kezelésében, ugyanakkor maguk a kutatók nyilván jobban értenek a vizsgált kérdéshez. A moderátor társas hatalma jelentkezhet abban, hogy gyakran a moderátorok magas iskolai végzettségúek, és esetleg magasabb státuszúak, mint a csoport résztvevói. Ennek kiküszöbölésére hasznos lehet, ha a moderátor érezteti a résztvevókkel, hogy ók olyan értékes információk birtokosai, amelyekkel a moderátor nem rendelkezik: hiszen nem ismerheti az ó véleményüket. 
10-vicsek.qxd 2006. 08.04. 11:11 Page 488

488 TELEPÜLÉSKUTATÁS - IV. FÓKUSZCSOPORTOS INTERJÚ

\section{KÖRNYEZET}

A beszélgetés környezetének fizikai jellemzói is hatással vannak a beszélgetésre. Például ha túl meleg és levegótlen a terem, akkor a résztvevók hajlamosak lehetnek siettetni a fókuszcsoport befejezését, és könnyebben válnak intoleránssá mások véleményei iránt (Fern 2001). Kintról bejövớ zaj zavarhatja a résztvevók koncentrációs képességét. Képek, díszek a falon, feltúnó tárgyak elvonhatják a figyelmet a beszélgetés témájáról (Stewart és Shamdashani 1990). Éppen ezért általában a fókuszcsoportokat viszonylag üres termekben szokták tartani. A helyszín formális/informális volta is befolyásolhatja a kapott adatokat (Green és Hart 1999). Egyik kutatásom során a helyi szervezók a fókuszcsoportot a falu kulturházának dísztermébe szánták. Több hatalmas asztalt elegáns terítókkel takartak be, és múvirágokat is elhelyeztek rajtuk. Az egész egy ünnepélyes dísztribün benyomását keltette. Ilyen berendezésekkel körülvéve valószínúleg kevésbé tudtak volna a résztvevók feloldódni. Éppen ezért átköltöztettem a fókuszcsoportot egy kisebb terembe, egy kisebb asztal köré, amelyen nem volt sem elegáns terító, sem múvirág.

Több kutatás is arra az eredményre jutott, hogy kisebb méretú termek és asztal körüli elhelyezés segítik leginkább a beszélgetéseket (Stewart és Shamdashani 1990). Fontos lehet, hogy mennyire különül el a fókuszcsoport tere más terektól, ahol mások, a fókuszcsoportban részt nem vevó személyek tartózkodnak. Az elkülönülés kérdéséhez kapcsolódik az alábbi példa: egy több teremból álló faluházban tartott fókuszcsoportnál azt tapasztaltam, hogy a terem, ahol a fókuszcsoport zajlott volna, nem volt kellóen elszigetelt a faluház többi részétól: a szomszédos teremtól egy üvegajtó választotta el, és az ajó felett egy ablak nyitva volt, lehetóvé téve, hogy azt lehessen gondolni, elképzelhetó, hogy a szomszéd szobában is hallatszik, amiról beszélgetünk. Becsukattam az ajtó feletti ablakokat, és megkértem egy szervezót, hogy ha lehet, érje el, a szomszédos teremben ne tartózkodjon senki. Mindez azért is volt fontos, mert a fókuszcsoport egyik témája a falubeli közösségi élet, a falubeli emberi kapcsolatok megítélése volt. Okkal lehetett feltételezni, hogy a résztvevók kevésbé lesznek ószinték, ha azt gondolják, hogy mások, különösen a faluházban tartózkodó önkormányzati emberek tudomására juthat véleményük.

Több fókuszcsoportos szakkönyv is hangsúlyozza annak figyelembevételét, hogy minden embernek van egy bizonyos térigénye, és negatívan érinti, ha mások a határon belülre kerülnek (Stewart és Shamdashani 1990; Fern 2001). Egy ilyen „határsértés” azzal is járhat, hogy például valaki nem vesz részt a beszélgetésben. A székek egymástól való távolságának meghatározásakor ezért ezt is figyelembe kell venni. Kutatások kimutatták, hogy az egyének közötti társas 
viszonyok jellege és különféle társadalmi-demográfiai tényezók befolyásolják az egyének térigényét (Fern 2001).

Befolyásolhatja a koncentrációképességet, az ellazulást, hogy van-e a résztvevók számára rágcsálnivaló és innivaló kikészítve. Ez elốsegíti azt, hogy ne vonja el valakinek a figyelmét, hogy éhes vagy szomjas, illetve a feloldódást is elósegítheti.

\section{IDÓTÉNYEZÓKK}

Eredményeinkre hatást gyakorolhat az is, hogy milyen napszakban tartjuk a csoportot. Többször tapasztaltam, hogy a szombat reggeli fókuszcsoportokon kevésbé fáradtak a résztvevók, és jobban tudnak koncentrálni, mint egy munkanapi esti órában tartott beszélgetésen.

A fókuszcsoportos beszélgetés hosszára is tekintettel kell lennünk. Azokra a kérdésekre, amelyekre a hosszú csoportülés végén jut csak idó, várhatóan kevésbé tudnak majd a résztvevók koncentrálni.

\section{TARTALOM}

A fókuszcsoport tartalma: a téma, az interjúvázlat/vezérfonal fó szempontjai, a kérdések jellemzói (pl. mennyire tágak), sorrendje, a kérdések stílusa és nyelvezete és a csoportok során alkalmazott speciális technikák mind olyan tényezók, amelyek befolyásolják a csoport menetét.

A téma szempontjából releváns lehet, hogy mennyire személyes, intim dologról van szó, hogy a kérdéssel kapcsolatban vannak-e eróteljes elvárások a társadalomban vagy abban a társadalmi rétegben, amelyból résztvevớink kikerülnek, arra vonatkozólag, hogy mi a „helyes” válasz.

Strukturáltabb fókuszcsoport esetén sok információt kaphat a kutató szorosan az eredeti kutatási elképzeléseihez kapcsolódóan, viszont kimaradhatnak fontos információk, amelyek hozzátartoznak a témához, de a kutató nem gondolt rá, és így nem tett fel rá vonatkozó, konkrét kérdést. Nyitottabb kérdés esetén meg lehet tudni, hogy az emberek maguk hogyan gondolkodnak egy adott témáról, mi az, amit ók fontosnak tartanak. Ezt azonban nehéz hatékonyság szempontjából betájolni, és nehezebb lehet az egyes csoportok eredményét is összehasonlítani` (Morgan és Krueger 1998).

${ }^{7}$ Éppen ezért a legtöbb fókuszcsoportban az ún. tölcsér-technikát alkalmazzák: a legnyitottabb, legtágabb kérdéseket a fókuszcsoport elején teszik fel, és azután egyre inkább szúkül a kérdések fókusza (Morgan és Krueger 1998). 
A fókuszcsoportok során a kutatók alkalmazhatnak technikákat, amelyek befolyásolják a szabad véleménynyilvánítást. Egyrészt a moderátor a csoport elején felhívhatja külön a figyelmet arra, hogy mindenkinek a valódi véleményére vagyunk kíváncsiak, és megkérhetjük a csoporttagokat az ellentétes vélemények eltúrésére. Másrészt, van, amikor a résztvevókkel a fókuszcsoport elótt kérdốvet töltetnek ki, amelyben leírhatják véleményüket a témáról. Miután írásban már elkötelezódtek egy adott nézet mellett, inkább várható, hogy kitartanak eredeti álláspontjuk mellett.

Különféle technikákkal befolyást gyakorolhatunk arra, hogy a társadalmilag kevésbé elfogadottnak tartott vélemények is meg tudjanak jelenni a fókuszcsoportban. Megtehetjük, hogy leíratjuk a résztvevókkel véleményüket, majd (név nélkül) felolvassuk a leírt véleményeket, így elérvén azt, hogy a csoport tagjai esetleg szembesülhessenek a ténnyel, hogy többen is, sót akár a többségük is egy társadalmilag nem helyesnek tartott nézetet vall. Egyik ismerósöm egyszer azt tervezte, hogy egy vállalati napon újonnan a vállalathoz került menedzserek körében fókuszcsoportot tart a cigányokkal szembeni elóítéletek témakörében. Mivel különösen diplomások körében erós lehet az az elvárás, hogy toleránsnak tüntessék fel magukat, kétséges, hogy az elóítéletes résztvevók mennyire merték volna nyíltan vállalni a saját véleményüket. Mivel szinte ez lett volna az elsó alkalom, amikor elbeszélgetnek egymással, úgy érezhették volna, hogy nagyon óvatosnak kell lenni mindazzal, amit mondanak, ráadásul nem is ismerhetik elózetesen a többiek nézeteit. Azt tanácsoltam a kutatónak, hogy írassa le elốzetesen mindenkivel a véleményét, úgy, hogy ne láthassák mit ír a másik, és tisztázza velük, nem lesz beazonosítva, hogy ki mit írt. Várhatóan írásban valamelyest szabadabban ki merik fejteni elóítéletes álláspontjukat is. Ezután szedje be, majd név nélkül olvassa fel a leírtakat. Ezáltal, ha van elóítéletes vélemény, azt látni fogják a résztvevók.

Projekciós kérdések alkalmazása is elósegíti a társadalmilag kevésbé elfogadott vélemények felszínre jutását. Ezek csökkentik az adott téma komolyságát, és segítségükkel másfajta gondolkodásmódokba is betekintést nyerhetünk, megkönnyíthetik a válaszok felszínre jutását olyan esetekben, amikor a résztvevók úgy érzik, válaszaik nem helyesek (Krueger és Morgan 1998). Projekciós kérdések közé tartoznak az analógiára vagy megszemélyesítésre vonatkozó kérdések, illetve a képzelet felhasználását igényló kérdések. Például a moderátor megkérdezi, hogy ha a vizsgált vállalat egy szék lenne, milyen szék lenne, és milyen érzés lenne ráülni.

A moderátorok különféle technikákat használhatnak annak érdekében is, hogy a domináns résztvevók kevésbé nyomják el a csoport félénkebb, szótlanabb tagjait. Egy, a fogyatékos személyek munkavállalási tapasztalatait vizsgáló 
fókuszcsoport ${ }^{8}$ során több domináns személyiségú résztvevó is akadt. Ók meglehetốsen agresszív módon megpróbálták uralni a beszélgetést, és másokat kevésbé hagytak volna szóhoz jutni. Itt közbeléptünk, és felhívtuk a figyelmet arra: fontos, hogy mindenkit hagyjanak megszólalni. Több esetben is külön rákérdeztünk a kevésbé domináns résztvevók véleményére. Elófordult, hogy amikor a domináns személyek rövid szünetet tartottak elbeszélésükben, hogy levegót vegyenek, ekkor gyorsan feltettem egy kérdést egy másik résztvevónek. Egy másik fókuszcsoportunkban az egyik résztvevó olyan nagy mértékben nem hagyta szóhoz jutni a többieket, hogy felmerült az is, hogy esetleg el kell küldeni a csoportból. Végül a fókuszcsoport két része között megkértük, hogy a többieket is hagyja beszélni, és megígértük neki, hogy majd készítünk vele külön interjút, amikor is részletesen elmondhatja a véleményét. Így sikerült elérni, hogy a fókuszcsoport második részében már nem jelentett problémát.

\section{A MEGFIGYELÉS TÉNYE}

Ismert dolog a társadalomtudományokban, hogy önmagában a kutatás alanyaira irányuló fokozott figyelem is befolyásolhatja a megfigyelt egyének viselkedését (Perrow 1997). Így azt várhatjuk, hogy a fókuszcsoporton közölt információkra hatással lehet az is, a résztvevók hogyan viszonyulnak ahhoz, hogy egy kutatás elemzi majd, amit mondanak, hogy videofelvétel készül róluk, hogy akár a helyszínen többen megfigyelik óket a csoport alatt (bár esetleg csak egy másik teremben, egy áltükör mögül), illetve hogy kit gondolnak a kutatás megbízójának.

Egy Szerencs környéki faluban tartott, romákból álló fókuszcsoporton, ahol a bizonytalanságérzet volt a téma, nagy szerencsémre azt a bemelegító kérdést tettem fel, hogy „Mire gondolt idefele jövet?” Kiderült, hogy többen úgy vélték, valamilyen politikai párt áll a felmérés mögött, illetve hogy az, amit mondanak, eljuthat politikusok fülébe.

Moderátor: - Hát talán kezdhetnénk is azzal, egy ilyen nyitó körrel, hogy mindenki elmondja a keresztnevét, bár gondolom, ismerik egymást, és hogy mire gondolt idefelé jövet... László?

László: - Én azt szeretném kérdezni, hogy ez, most ez a kutatás célja, ez most valami pártot képvisel, ha jól tudom?

Moderátor: - Igen, ez fontos. Nem, ez teljesen független, semmilyen párthoz nem kapcsolódik, és politikához sem kapcsolódik, és nem is fogják politikusok ezt fölhasználni. Tehát ez kizárólag tudományos célú.

${ }^{8}$ Erról a fókuszcsoportos vizsgálatról bóvebben lásd: Keszi és Vicsek 2002. 
(...)

Jenó: - Idejövet, akkor gondolkodtam azon, hogy most jelen leszek, minden, és igazából azon gondolkodtam, hogy lesz-e ennek értelme. Valahol, valamikor. Most tudom, hogy felmérnek kutatásokkal, hogy most hogyan élnek Magyarországon, fóleg a cigányság. Most ez javítja valamit a helyzetünket a jövóben, vagy marad? (...)

Jenó: - Így politikusok fogják ezeket látni?

Moderátor: - Nem.

Jenó: - Mert arra gondoltam, hogy ha a felmérés megtörténik, lesz egy statisztikai adat, most ezt valahová csak le kell adni, mert valaki, egy cég finanszírozza ezt a kutatást.

(2001, Szerencs környéki kis faluban roma fókuszcsoport)

Mindez többek között azért lehet lényeges, mert a csoporttagok egy része a fókuszcsoport késóbbi részében kifejtette, hogy úgy vélik, életük teljesen a politikusok hatalmától függ:

Erzsébet: - Ha megnézem, ezen [a jövốn] mi nem is tudunk változtatni, kisemberek, ezen nem tud más változtatni, csak a kormány. Nem? (...) Te csak vagy, te csak vagy, itten a döntéseket a nagy emberek hozzák a kis emberekról, hát attól függünk... Jön a választás, igaz? Hát itt azon múlik minden. Hogy az, a szociálpolitikai kedvezmények, meg mit tudom én, hogy az, a családügyi minisztérium, hogy mit fog ott, hátrányosabb, vagy még attól is szegényebb réteggel csinálni, mert ez nem rajtunk múlik. Hogy mit fog hozni a miniszter...

(2001, Szerencs környéki kis faluban roma fókuszcsoport)

Nyilván ha a résztvevók úgy hiszik, hogy amit mondanak, azt politikusok látni fogják, akkor gondolhatják azt, hogy amit a fókuszcsoporton mondanak, az tulajdonképpen egy „üzenet” a politikusok felé, és ez befolyásolhatja azt, milyen információkat közölnek.

\section{A befolyásoló tényezők bevonása az elemzésbe}

A fókuszcsoportokkal kapcsolatos szakirodalmat olvasva rögtön szembetúnik, hogy mennyivel több és részletesebb leírása található annak, hogy miként tervezzünk meg egy fókuszcsoportos kutatást, hogyan válasszuk ki a résztvevóket, a moderátort, stb., és kevesebb szó esik arról, hogy miként elemezzük a fókuszcsoportokat. Úgy túnik, hogy a fókuszcsoport-módszertan legkevésbé kifejlesztett része a fókuszcsoportok elemzésének kérdésköre.

Az elemzéssel kapcsolatban két fó irányzat különíthetó el. Az egyik irányzat képviselói az elemzéskor nem veszik tekintetbe a fókuszcsoportok szituációját. 
A másik, új irányzat pedig a befolyásoló tényezók egy részének figyelembevétele mellett érvel. Amellett kardoskodnak, hogy fontos figyelembe venni és elemezni az interakciókat, a csoportdinamikát és a csoportszituációt, és azt, hogy a résztvevókre külsó és belsó nyomás nehezedik a konformitás irányába (Kitzinger 1994; Kid és Parshall 2000; Sim 1998). Az újabb irányzat egyik megfogalmazója azt írja egyik cikkében, hogy bár átnézett több száz fókuszcsoportelemzést tartalmazó cikket, egyikben sem fordult eló, hogy elemezték volna a csoportszituációt, a résztvevók közötti interakciókat (Kitzinger 1994). Az új irányzat képviselói többnyire maguk sem jutottak még el odáig, hogy olyan fókuszcsoport-elemzéseket végezzenek, ahol a csoportszituációt is figyelembe veszik. Egyelóre gyakran megmaradtak pusztán a csoportdinamika, a csoportszituáció figyelembevételének hangoztatása mellett, anélkül hogy kidolgozták volna részletesen ennek a módszerét, illetve alkalmazták volna elemzéseik során. Ráadásul, ók többnyire pusztán azt hangsúlyozzák, hogy figyelembe kell venni, hogy a fókuszcsoport egy csoportos helyzet, de nem foglalkoznak olyan egyéb tényezókkel, amelyek szintén befolyásolják a fókuszcsoporton elhangzottakat, mint például a környezet hatása stb.

A csoporthatások figyelembevétele mellett érveló Sim (1998) felhívja arra a figyelmet, hogy a konszenzus és egyet nem értés elemzése tekintetében létezik egyfajta aszimmetria. Míg ha különbözó, eltéró, egymással ütközó vélemények jelennek meg a csoportban, akkor feltételezhetó, hogy ez a divergencia a véleményekben az egyéni nézetek terén is megvan, addig az eltéró vélemények hiánya egy fókuszcsoportban nem szükségképpen az egyéni nézópontok konszenzusát tükrözi, hanem a nyilvános konformitás irányába mutató erós csoportnormákat is jelentheti. Éppen ezért korlátozottabban lehet következtetéseket levonni, amikor konszenzus jelenik meg a csoportokban. Ilyenkor fontos megvizsgálni, hogy mennyiben okozhatta az eredményeket a konformitás, az elnyomás vagy konfliktuskerülés (Kidd és Parshall 2000). Bizonyos módszerekkel lehet javítani a következtetések erején: például, ha a fókuszcsoport elótt kérdóivet töltetünk ki a résztvevókkel, akkor azt összevethetjük azzal, amit a fókuszcsoport során mondanak. Ez segíthet minket annak eldöntésében, hogy a konszenzus valódi vagy csoportnyomás hatására jött létre.

A „bizonytalanságérzet” témájú fókuszcsoportos vizsgálat eredményeinek elemzésekor is összevetettem a szúrókérdóívet és a fókuszcsoportokon elhangzottakat. Azt találtam, hogy az emberek kérdốívben leírt egyéni véleményei álta-

${ }^{9}$ Bonyolítja a helyzetet, hogyha eltérést tapasztalunk a szúrókérdôívben leírtak és a fókuszcsoporton elmondottak között, akkor ez amiatt is létrejöhetett, mert a résztvevók megváltoztatták valódi véleményüket a vita hatására. A véleménymódosulás lehet csak átmeneti, de akár tartós is. Ugyanakkor bizonyos témák esetén kevésbé várható a belsố vélemény megváltoztatása, mint egyes más kérdéskörök esetén. 
lában megjelentek a fókuszcsoportok során, még akkor is, ha ez az álláspont szemben állt a többségi nézóponttal. Ugyanakkor többször volt rá példa, hogy miután kiderült, hogy egy nézópont kisebbségben van, ezután már a kisebbségben lévók kevesebbet beszéltek róla. Elófordult olyan eset is, hogy emiatt valaki valamelyest el is csendesült a fókuszcsoport során, és rákérdezésre is csak nehezen szólalt meg újra. Egyes esetekben a kisebbségi véleményt a többségivel szemben inkább kompatibilis vagy finomított formában fogalmazták meg a kisebbségi vélemény pártján állók, illetve véleményüknek azokat az elemeit hangsúlyozták inkább, amelyek egyeztek a csoport többi résztvevójéével. Az erósebb személyiséggel rendelkezók azonban gyakran kiálltak a nézetük mellett, és volt, hogy részletesen beszéltek róla azután is, hogy nyilvánvalóvá vált, a csoport nagy része másként látja. Ez olykor kisebb konfliktusokhoz is vezetett. Mindezek alapján a kutatás során azt a következtetést vontuk le, hogy úgy túnik, a nyilvános konformitás irányába mutató nyomás általában nem olyan nagy a „bizonytalanság” téma kapcsán, hogy a kisebbségi vélemények ne merjenek egyáltalán megjelenni.

Az elózó részben kitértünk arra is, hogy a csoportszituáció egyéb módokon is befolyásolhatja az elhangzottakat: például egyes témákat túl intimnek érezhetnek az emberek ahhoz, hogy másokkal megbeszéljék, illetve a résztvevók olyan dolgokról beszélnek, amelyról úgy vélik, mások számára is érdekes lehet megvitatni. Éppen ezért amennyiben azt találjuk, hogy egy tényezó dominálja a beszélgetéseket, célszerú lehet azt is bevonni az elemzésbe, hogy kiderüljön, e mögött az áll-e, hogy ténylegesen az a legfontosabb tényezó a résztvevók számára, vagy pedig elképzelhetó, hogy pusztán a fenti mechanizmusok miatt vált hangsúlyossá egy téma. A bizonytalanságérzetes kutatásnál például azt találtam, hogy a fókuszcsoportok többségében az anyagi és a munkához kapcsolódó bizonytalanságról beszéltek a legtöbbet a résztvevók. Ugyanakkor azt találtam, hogy nemcsak a legtöbbet beszéltek róla, hanem ók maguk is ezt értékelték a legfontosabb bizonytalansági tényezónek. Lehetséges lett volna az is, hogy egy csoport elótt nem akartak az emberek olyan témákkal elóhozni, amelyet az anyagi és a munkabiztonság témakörénél személyesebbnek tartanak. Másfelól, az is elképzelhetó lett volna, hogy úgy érezték, olyan dolgokról kell beszélniük, amelyhez mások kapcsolódni tudnak és akarnak, és úgy gondolták, hogy az anyagiak és a munka ilyen közös érdeklódési terület lehet. Ugyanakkor voltak arra utaló jelek a fókuszcsoportokban, hogy az anyagiak és a munka miatti biztonsághiány nemcsak a csoportkontextusból kifolyólag jelentkezett hangsúlyosan. Egyfelól, a résztvevók gyakran beszéltek személyes témákról, mint például válás, nehézségek a házasságban stb. Másfelól, a csoport elótt egyénileg kitöltött kérdóívekben is az anyagi és munkahelyzet jelentkezik domináns bizonytalansági faktorként. 
Úgy véljük, hogy az interakciós tényezókön túl a többi korábban bemutatott befolyásoló tényezó figyelembevétele is hasznos lehet egy elemzés készítése során. Több, fókuszcsoportok módszertanával foglalkozó könyv kitér a fókuszcsoportok kimenetelére hatással levó tényezók tágabb körére, ezekról azonban nem beszélnek az elemzéssel foglalkozó fejezetben (Stewart és Shamdasani 1990; Fern 2001). Ezek a könyvek azt hangsúlyozzák, hogy a fókuszcsoportok megszervezésénél figyelni kell ezekre a tényezókre, mivel ha más alapjellemzókkel rendelkezó csoportot hozunk létre, más lesz az eredményünk is. Számunkra azonban logikusnak túnik, hogy ha elismerjük, hogy ezek a faktorok kihatással vannak a fókuszcsoportok kimenetelére, akkor azt az elemzésben is érvényesítsük. Ha figyelembe vesszük, hogy adataink nem függetlenek a konkrét szituációtól, hanem beleágyazódnak, következtetéseink gazdagabbak és tanulságosabbak lehetnek.

Több módon is végre lehet hajtani a befolyásoló tényezók beemelését az elemzésbe: megoldható úgy is, hogy a szituációelemzés nem különül el a tematikus elemzéstól, de végrehajtható úgy is, hogy az elemzés külön részben foglalkozik a fókuszcsoportok befolyásoló tényezóivel, és külön részben a csoporton elhangzottak tematikus elemzésével.

\section{Összegzés és következtetések}

Jelen írásban bemutattunk a fókuszcsoportok kimenetelére hatást gyakoroló tényezóket. A fókuszcsoporton elhangzottakat befolyásolják többek között az interakciós tényezók, a személyes jellemzók, a környezet, az idótényezók, a tartalom és a megfigyelés ténye. Majd pedig amellett érveltünk, hogy ezeket a tényezóket célszerú figyelembe venni, amikor fókuszcsoport elemzést végzünk.

Fontos érv a fókuszcsoportok módszere mellett, hogy a hétköznapi életünk során sem izoláltan élünk, hanem különféle társas hálózatok tagjai vagyunk (Kitzinger 1994). Gyakran vitatjuk meg másokkal véleményünket, beszélgetünk másokkal különféle témákról. A fókuszcsoportos beszélgetéseknél tapasztalható csoportdinamikai hatásoknak ekkor is ki vagyunk téve. Éppen ezért a fókuszcsoportok módszere különösen hasznos lehet akkor, amikor csoportnormákat, csoportfolyamatokat szeretnénk vizsgálni.

Nem igaz az a fókuszcsoportokkal szemben felhozott vád, hogy az egyéni interjú vagy a kérdớiv szükségképpen jobban tükrözi az egyéni véleményeket, mint a fókuszcsoport. Elképzelhetố akár, hogy valaki azáltal, hogy elmond egy dolgot a csoportban, megtöri a jeget, és ennek hatására mások is elmesélik élményeiket, amit más szituációban nem vállaltak volna fel (Kitzinger 1994). Az egyéni mélyinterjú vagy a kérdóív-szituáció sem egy semleges szituáció, amely 
mindig híven tükrözné az egyéni véleményeket. Egy angliai kutatás vezetói például azt a meglepó eredményt kapták, hogy abban a régióban, ahol nagyobb volt a környezetszennyezés, a kérdốivre választ adók kevésbé tartották fontos problémának ezt megemlíteni, mint a többi régióbeliek. Fókuszcsoportok alkalmazása révén derült ki, hogy a kérdóívben azért bagatellizálták el a kérdezettek a problémát, mert már nagyon elegük volt abból, hogy a környezetszennyezéssel kapcsolatban mindenki óket kutatja, és mindenki óket akarja sajnálni a helyzetük miatt. Ezért a kérdóívben feltüntetett álláspontjuk tulajdonképpen egyfajta tiltakozást fejezett ki azzal szemben, hogy rajtuk szánakozzanak (Waterton és Wynne 1999).

Mint a fenti példa is illusztrálja, valójában nemcsak a fókuszcsoportos vizsgálatoknál, hanem más módszerek alkalmazása esetén is oda kellene figyelni a konkrét szituáció jellemzóire, különféle befolyásoló tényezókre, amelyek kihatással vannak a végeredményre, és figyelembe kellene venni ezeket az elemzésnél.

\section{IRODALOM}

Albrecht, Terrance L. et al. (1993): Understanding Communication Processes in Focus Groups. In: David L. Morgan (szerk.) (1993): Successful Focus Groups. Advancing the State of the Art. Thousand Oaks/London/New Delphi: Sage, 51-64.

ARIES, E. (1976): Interaction patterns and themes of male, female, and mixed groups. Small Group Behavior, 7, 7-17.

Carey, Martha Ann (1994): Capturing the group effect in focus groups: A special concern in analysis. Qualitative Health Research, Vol. 4. Issue 1. Február, 123-128.

Chiv, Lai-Fong és Deborah Knight (1999): How useful are focus groups for obtaining the views of minority groups? In: Rosaline S. Barbour és Jenny Kitzinger (szerk.): Developing Focus Group Research. Thousand Oaks/ London/New Delphi: Sage, 99-112.

Green, Judith és Laura Hart (1999): The impact of context on data. In: Rosaline S. Barbour és Jenny Kitzinger (szerk.): Developing Focus Group Research. Thousand Oaks/London/New Delphi: Sage, 21-23.

Farquhar, Clare (1999): Are focus groups suitable for 'sensitive' topics? In: Rosaline S. Barbour - Jenny Kitzinger (szerk.): Developing Focus Group Research. Thousand Oaks/London/New Delphi: Sage, 47-63. 
Fern, Edward F. (2001): Advanced Focus Group Research. Thousand Oaks/ London/New Delphi: Sage.

Hewstone, Miles et Al. (1995): Szociálpszichológia. Budapest: Közgazdasági és Jogi Könyvkiadó.

Keszi Roland és VicseK Lilla (2002): Fókuszcsoport elemzés. In: Komáromi Róbert (szerk.) Kutatási zárótanulmány. A fogyatékos és megváltozott munkavállalók foglalkoztatásáról a TOP 200 adatbázis alapján. Budapest: Kézirat, 131-186.

Kidd, Pamela S. És Parshall, Mark B. (2000): Getting the Focus and the Group: Enchancing Analytical Rigor in Focus Group Research. Qualitative Health Research, Vol. 10. Issue 2. May, 293-309.

KitZinger, Jenny (1994): The methodology of Focus Groups: the importance of interaction between research participants. Sociology of Health and Illness, Vol. 16., 1, 103-121.

Kitzinger, JenNy (1995): Introducing Focus Groups. BMJ (British Medical Journal), Vol. 311, Issue 7000, 299-303.

Krueger, Richard A. (1988): Focus groups: A practical guide for applied research. Newbury Park, CA: Sage.

Michell, LynN (1999): Combining focus groups and interviews: telling how it is, telling how it feels. In: Rosaline S. Barbour és Jenny Kitzinger (szerk.): Developing Focus Group Research. Thousand Oaks/London/New Delphi: Sage, 36-46.

Morgan, David L. (1993): Successful Focus Groups. Advancing the State of the Art. Thousand Oaks/London/New Delphi: Sage.

Morgan, David L. és Krueger, Richard A. (1998): The Focus Group Kit. Thousand Oaks/London/New Delphi: Sage.

Perrow, Charles (1997): Szervezetszociológia. Budapest: Osiris.

Sim, Julius (1998): Collecting and Analysing Qualitative Data: Issues Raised by the Focus Group. Journal of Advanced Nursing, Vol. 28, Issue 2, August, 345-353.

Stewart, David W. és Shamdasani, Prem N. (1990): Focus Groups: Theory and Practice. Thousand Oaks/London/New Delphi: Sage.

VicseK LiLla (2001): A környei fókuszcsoport eredményei. In: Füleki Dániel (szerk.): Információs Technológia és Szolgáltató Közigazgatás I. kötet. Tapasztalatok. Budapest: BKÁE Szociológia és Szociálpolitika Tanszék, 55-62.

VICSEK Lilla (2003): Beszélgetés a prostitúcióról: két fókuszcsoport tanulságai. Médiakutató, 3.

Vicsek Lilla (2004): Bizonytalanságérzet a mai Magyarországon - Egy fókuszcsoportos vizsgálat eredményei. Társadalomkutatâs, 22: (2-3), 279-313. 
498 TELEPÜLÉSKUTATÁS - IV. FóKUSZCSOPORTOS INTERJÚ

Waterton, Claire És Wynne, Brian (1999): Can focus groups access community views? In: Rosaline S. Barbour - Jenny Kitzinger (szerk.) Developing Focus Group Research. Thousand Oaks/London/New Delphi: Sage, 127-143.

Werdy, Gordon és Langmaid, Roy (1997): Kvalitatív Piackutatás. Budapest: HVG Rt. 